\title{
Incidence and Spatial Distribution of Viruses in Hop Gardens of Washington State
}

Sarah J. Pethybridge, Tasmanian Institute of Agricultural Research, University of Tasmania, School of Agricultural Science, GPO Box 252-54, Hobart, Tasmania, 7001, Australia; Mark E. Nelson, Kenneth C. Eastwell, Robert E. Klein, and Stephen T. Kenny, Washington State University, Irrigated Agriculture Research and Extension Center, 24106 North Bunn Road, Prosser 99350; and Calum R. Wilson, Tasmanian Institute of Agricultural Research, University of Tasmania, School of Agricultural Science, GPO Box 252-54, Hobart, Tasmania, 7001, Australia

\begin{abstract}
Pethybridge, S. J., Nelson, M. E., Eastwell, K. C., Klein, R. E., Kenny, S. T., and Wilson, C. R. 2002. Incidence and spatial distribution of viruses in hop gardens of Washington State. Plant Dis. 86:661-665.

The incidences of Hop latent virus (HpLV), Hop mosaic virus (HpMV), and American hop latent virus (AHLV), members of the genus Carlavirus, and Prunus necrotic ringspot virus and Apple mosaic virus, members of the genus Ilarvirus, were assessed for two hop cultivars, Horizon and Nugget, in Washington State. The spatial distribution of plants infected by the carlaviruses was assessed in two Horizon gardens in 2000 and one Nugget garden in 1993, 1994, and 1995. In the first Horizon garden (garden 1) and the Nugget garden, plants were separated by $2.1 \mathrm{~m}$ within and between rows. In these gardens, cultivation and the wide plant spacing discouraged contact between plants in either direction. In the second Horizon garden (garden 2), plants were separated by $4.3 \mathrm{~m}$ between rows and $1.0 \mathrm{~m}$ within rows. In all gardens, mechanical operations operated predominantly along rows; however, the closer plant spacing within rows in garden 2 permitted contact between adjacent plants within rows. In both Horizon gardens, the distribution of plants infected with HpMV was aggregated within rows. However, the distribution of plants infected with HpLV and AHLV was strongly influenced by contact between plants. In the Nugget garden, the distribution of plants infected by all three carlaviruses was autocorrelated within rows by 1995 .
\end{abstract}

Additional keywords: Humulus lupulus, viral epidemiology

Hops were grown on approximately 15,000 ha in the Pacific Northwest region of the United States in 2000, primarily in the Yakima Valley of Washington, the Caldwell and Bonner's Ferry regions of Idaho, and the Willamette Valley of Oregon (7). Five viruses commonly occur in hop (Humulus lupulus L.) gardens in the Pacific Northwest, Hop latent virus (HpLV), Hop mosaic virus (HpMV), and American hop latent virus (AHLV), members of the genus Carlavirus, and Apple mosaic virus (ApMV) and Prunus necrotic ringspot virus (PNRSV), members of the genus Ilarvirus (15). Infection by HpMV and $\mathrm{HpLV}$ has been reported from commercial hop gardens in Europe (11), New Zealand (14), Australia (18,23), China (30), and South Africa (29). AHLV is believed to be prevalent in commercial hop gardens in the United States (15), although

Corresponding author: S. J. Pethybridge

E-mail: sarah_jp@utas.edu.au

Current address of Robert E. Klein: California Pistachio Commission, 1318 E. Shaw Ave., Suite 420, Fresno, CA 93710-7912.

Accepted for publication 6 February 2002.

Publication no. D-2002-0412-01R

(C) 2002 The American Phytopathological Society low levels of AHLV infection have been reported in New Zealand (14) and in breeder's introductions in the United Kingdom from which AHLV was subsequently eradicated (2).

The natural host range of these three carlaviruses is limited to $H$. lupulus $(1,2)$. HpMV can be transmitted between hop plants by spring alates of the aphid Phorodon humuli (Schrank) $(1,20)$, which is known to occur in Washington (9), and by the aphid Macrosiphum euphorbiae (Thomas) $(1,19)$. Other studies demonstrated that apterous stages of $P$. humuli and the aphid Myzus persicae (Sulzer) are also vectors of HpMV (1). P. humuli is also capable of transmitting HpLV and AHLV (2). Alternative vectors of $\mathrm{HpLV}$ and AHLV have not been identified. Although quantitative studies have not determined that $P$. humuli is a more efficient vector of HpLV, HpMV, and AHLV than other aphid species $(8,11), P$. humuli is regarded as the most important vector because it is the dominant aphid species found on hops in Europe (11) and Washington (9). Mechanical transmission is considered the most likely means of spread of the ilarviruses between hop plants (27). Greenhouse trials have supported this theory through successful transmission of PNRSV by simulated cultural operations such as mowing and pruning $(6,21)$, training and harvesting
$(12,27)$, direct contact of foliage (21), and root grafting $(12,21)$.

Knowledge of the incidence of viruses, the spatial distribution of virus-infected plants, associations between different viruses, and the economic impact of viruses on hop production are prerequisites for the implementation of cost-effective management strategies. The objectives of this study were to assess the level of virus reinfection in hop gardens and to determine whether different planting patterns influenced the spatial distribution of virusinfected plants in hop gardens in Washington.

\section{MATERIALS AND METHODS}

Horizon gardens. The incidences of HpLV, HpMV, AHLV, ApMV, and PNRSV were assessed in 10 commercial hop gardens of the cultivar Horizon in the Yakima Valley between 5 and 10 July 2000. The hop gardens selected ranged in age from 1 to 3 years. Seven of the gardens were established with planting material derived from virus-free mother plants. The remaining gardens were planted with root cuttings from gardens that had been planted with virus-tested material. However, mother plants within the gardens were not retested for virus infection prior to cuttings being taken. To assess the incidence of each virus, three young expanding leaves were collected from 80 plants systematically selected in a diagonal transect across each garden.

The influence of planting pattern on the spatial distribution of virus-infected plants was assessed in two gardens planted in 1998 and located $0.8 \mathrm{~km}$ apart on the same commercial hop farm. In garden 1, plants were arranged in a $36 \times 14$ pattern (36 plant spaces within each of 14 rows) with a plant spacing of $2.1 \mathrm{~m}$ within and between rows. In this garden, contact of the basal growth of adjacent plants was minimal both within and between rows because of frequent cultivation and use of desiccant herbicides (paraquat). Cultivation was carried out exclusively along rows. In garden 2, plants were arranged in a $25 \times 20$ pattern ( 25 plant spaces within each of 20 rows) with a plant spacing of $4.3 \mathrm{~m}$ between rows and $1.0 \mathrm{~m}$ within rows. In garden 2, all mechanical operations (e.g., spraying, stringing, and harvesting) were carried out exclusively along rows, which 
permitted extensive contact of basal rows. The total numbers of plants in gardens 1 and 2 were 444 and 476, respectively, as plants were not grown on poles supporting overhead wires. Apart from planting pattern, agronomic practices such as basal growth control by desiccant herbicides, irrigation, nutrition, and weed and pest control were similar in both gardens.

Nugget garden. Infection by viruses was monitored in a research hop garden of the cultivar Nugget. The garden was established in 1991 at the Washington State University Irrigated Agriculture Research and Extension Center in Prosser. At the time of planting, the material was certified as virus-free by serological assays. Plants were arranged in a $46 \times 12$ pattern (46 plant spaces within each of 12 rows), with $2.1 \mathrm{~m}$ between plants, both within and between rows. The total number of plants was 518 , as plants were not planted adjacent to poles supporting overhead wires. The majority $(85 \%)$ of mechanical operations and movement of garden traffic occurred along rows, while the remainder went across rows. The incidence of $\mathrm{HpLV}$, HpMV, and AHLV in all plants was assessed in May of 1993, 1994, and 1995. Agronomic practices such as irrigation, nutrition, and weed and pest control were similar to those carried out in commercial hop gardens in the region.

Serological assays for viruses. Three young, expanding leaves were collected randomly per plant. Subsamples (0.1 g) containing equal weight portions of all three leaves were homogenized in $1.0 \mathrm{ml}$ of $0.01 \mathrm{M}$ phosphate-buffered saline $(\mathrm{pH}$ 7.4) containing Tween 20 ( $2.5 \mathrm{ml} /$ liter), egg albumin ( $2 \mathrm{~g} /$ liter), and polyvinyl pyrrolidone ( $\mathrm{MW}=40,000 ; 20 \mathrm{~g} /$ liter), using a rotary leaf press (Erich Pollähne $\mathrm{GmbH}$, Wennigsen, Germany). Sap extracts (100 $\mu \mathrm{l}$ per well) were tested in duplicate by growth between adjacent plants within

double-antibody sandwich enzyme-linked immunosorbent assay (10) using polyclonal antisera to HpLV, HpMV, AHLV, PNRSV, and ApMV, with positive, negative, and buffer controls for each virus on each plate. Polyclonal antisera to PNRSV, ApMV, and HpMV were produced and gifted by C. B. Skotland (formerly of Washington State University, Prosser). Polyclonal antiserum to HpLV was obtained from Horticultural Research International, UK. Polyclonal antiserum to AHLV was gifted from R. O. Hampton (formerly of the USDA-ARS, Corvallis, OR). Absorbance $\left(A_{405 \mathrm{~nm}}\right)$ was measured using a Model 7520 microtiter plate reader (Cambridge Technology, Inc., Watertown, MA). Samples with absorbance values greater than the mean of the negative control plus three times the standard deviation of the mean of the negative controls were considered virus infected (25).

Spatial analysis. The spatial patterns of virus-infected plants of the cultivar Horizon in gardens 1 and 2 in 2000, and of cultivar Nugget in the WSU garden in 1993, 1994, and 1995, were characterized by ordinary runs analysis (16) and a modified version of radial correlation analysis (13). Spatial distributions were not analyzed by either method if the incidence of virus-infected plants was less than $5 \%$ or greater than $95 \%$. Ordinary runs analysis assessed whether infected plants either within or between rows were significantly aggregated $(P=0.05)$. A run was defined as a succession of one or more healthy or infected plants flanked by a plant of the opposite infection state (16). Ordinary runs analyses were performed using the software "Patchy" (17). The number of rows with significant aggregation (nonrandom sequence) of infected and healthy plants compared with the total number of rows, where ordinary runs could be calculated, was used as a measure of the extent of

Table 1. Incidence of viruses in 12 commercial hop gardens of the cultivar Horizon in the Yakima Valley of Washington State in July 2000

\begin{tabular}{lccccc}
\hline & \multirow{2}{*}{$\begin{array}{c}\text { Age of garden } \\
\text { (years) }\end{array}$} & HpLV & HpMV & AHLV & Ilarviruses $^{\mathbf{b}}$ \\
\cline { 3 - 6 } Garden & 1 & 38 & 11 & 36 & 2 \\
\hline $\mathrm{A}$ & 1 & 46 & 15 & 21 & 0 \\
$\mathrm{~B}$ & 1 & 76 & 13 & 24 & 0 \\
$\mathrm{C}$ & 2 & 64 & 18 & 30 & 0 \\
$\mathrm{D}$ & 2 & 88 & 30 & 34 & 1 \\
$\mathrm{E}$ & 2 & 69 & 19 & 34 & 0 \\
$\mathrm{~F}$ & 3 & 68 & 20 & 33 & 6 \\
$\mathrm{G}$ & 3 & 70 & 18 & 35 & 6 \\
$\mathrm{H}$ & 3 & 78 & 34 & 39 & 6 \\
$\mathrm{I}$ & 3 & 60 & 26 & 32 & 1 \\
$\mathrm{~J}$ & 3 & 52 & 24 & 30 & 1 \\
$\mathrm{~K}^{\mathrm{c}}$ & 3 & 71 & 29 & 35 & 1 \\
$\mathrm{~L}^{\mathrm{c}}$ & 3 & &
\end{tabular}

a Three randomly selected leaves were collected from each of 80 systematically selected plants along a diagonal transect across each garden. Presence of Hop latent virus (HpLV), Hop mosaic virus (HpMV), and American hop latent virus (AHLV), members of the genus Carlavirus, and Ilarviruses established by double-antibody sandwich enzyme-linked immunosorbent assay (10).

${ }^{\mathrm{b}}$ Ilarviruses $=$ combined incidence of Prunus necrotic ringspot virus and Apple mosaic virus.

${ }^{\mathrm{c}}$ Gardens $\mathrm{K}$ and $\mathrm{L}$ refer to gardens 1 and 2, respectively, used for studies on the spatial distribution of carlaviruses in Horizon gardens. aggregation. Radial correlation analysis was carried out using a modified version of the program 2DCORR that measured the probability of deviation from a random spatial distribution, using a KolmogorovSmirnov one-tail analysis $(P<0.05)(24)$, based on a cumulative probability density function for the total number of pairs of infected plants within a given distance. The distance $r$ was estimated as the length over which disease was correlated $(13,22)$. Comparisons of the results of radial correlation analyses with ordinary runs analyses were made by examination of the probability values within and between rows, without the application of a Bonferroni correction (13).

\section{RESULTS}

Incidence of viruses in Horizon gardens. Incidence of the three carlaviruses in the Horizon gardens was generally high (Table 1). Incidence of HpLV ranged from 38 to $76 \%, 64$ to $88 \%$, and 52 to $78 \%$ in 1-, $2-$, and 3-year-old plants, respectively. Incidence of HpMV ranged from 11 to $15 \%, 18$ to $30 \%$, and 18 to $34 \%$, in $1-, 2-$, and 3-year-old gardens, respectively. AHLV was detected in 21 to $36 \%, 30$ to $34 \%$, and 30 to $39 \%$ of the plants sampled in 1-, 2-, and 3-year-old gardens, respectively. The combined incidence of ApMV and PNRSV ranged from 1 to $6 \%$ in all gardens. In four of the gardens, no ilarviruses were detected (Table 1).

Incidence of viruses in the Nugget garden. All three carlaviruses were detected in the WSU hop garden in 1993, only 2 years after planting the virus-free material (Table 2). Incidences of all three viruses increased with time in Nugget. In 1993, 1994, and 1995, incidence of HpLV was 27,44 , and $74 \%$, respectively; incidence of HpMV was 10, 15, and $32 \%$, respectively; and incidence of AHLV was 23,35 , and $57 \%$, respectively (Table 2 ).

Spatial distribution of virus-infected plants in Horizon gardens. In garden 1, the low number of rows with significant aggregation $(P<0.05)$ of plants infected with HpLV and AHLV (Table 2), and the absence of significant aggregation both within and between rows (Table 3), suggested a random distribution of plants infected with HpLV and AHLV. Ordinary runs analysis of the spatial pattern of plants infected with HpMV indicated that $21 \%$ of rows in the primary direction of cultivation had significant $(P<0.05)$ clustering of infected plants (Table 2). This was supported by a significant probability $(P=$ 0.01 ) of a nonrandom distribution of infected plants when analyzed for radial correlation (Table 3 ). In garden 2 , ordinary runs analyses demonstrated that the number of rows with significant $(P<0.05)$ aggregation of plants infected by all three carlaviruses was greater in the direction of basal growth contact (within rows) than between plants separated by the larger 
spacing between rows $(4.3 \mathrm{~m})$ (Table 2). This was supported by the absence of significant radial correlation between rows (Table 3) and significant correlation between rows for each carlavirus (Table 3 ). The low incidence of ilarviruses in gardens 1 and 2 (Table 1) prevented analysis of the distribution of infected plants.

Spatial distribution of virus-infected plants in the Nugget garden. Ordinary runs analyses indicated a low proportion of rows in either direction had significant $(P$ $<0.05$ ) aggregation of plants infected with HpLV in 1993 and 1994. However, in 1995, significant aggregation of infected plants within rows occurred in $25 \%$ of rows in the primary direction of garden traffic, while no significant aggregation occurred in the opposite direction (between rows) (Table 2). This was supported by results from radial correlation analyses that failed to detect significant radial correlation in all 3 years, or anisotropic (skewed in one direction only) correlation in either direction in 1993 and 1994 (Table 3). Analysis of the distribution of plants infected with HpMV indicated that the number of rows with significant $(P=0.05)$ aggregation of infected plants in the direction of garden traffic was 25, 12, and 4 times higher than the number of rows with significant aggregation in the opposite direction in 1993, 1994, and 1995, respectively (Table 2). This was supported by results from radial correlation analysis that detected significant anisotropic correlation within rows in 1994 and 1995 (Table 3). Ordinary runs analyses of the distribution of plants infected with AHLV indicated that a low proportion of rows in both directions had significant $(P<0.05)$ aggregation of infected plants in 1993. In 1994 and 1995, there were 9 and 4 rows, respectively, with significant $(P<0.05)$ aggregation of infected plants in the same direction as the movement of garden traffic, versus no rows with significant aggregation in the opposite direction (between rows) for both

Table 2. Results of ordinary runs analyses of the spatial distribution of plants infected with Hop latent virus (HpLV), Hop mosaic virus (HpMV), and American hop latent virus (AHLV), members of the genus Carlavirus, in hop gardens of the cultivars Horizon (2000) and Nugget (1993, 1994, and 1995) in Washington State

\begin{tabular}{|c|c|c|c|c|c|c|}
\hline \multirow[b]{2}{*}{ Cultivar } & \multirow{2}{*}{$\begin{array}{l}\text { Garden and spacing } \\
\text { between plants }^{b}\end{array}$} & \multirow{2}{*}{$\begin{array}{c}\text { Year of } \\
\text { evaluation }\end{array}$} & \multirow[b]{2}{*}{ Virus } & \multirow{2}{*}{$\begin{array}{l}\text { Incidence }(\%) \text { of } \\
\text { infected plants }\end{array}$} & \multicolumn{2}{|c|}{$\begin{array}{c}\text { Rows with significant aggregation } \\
\text { of infected plants }(\%)^{\mathrm{a}}\end{array}$} \\
\hline & & & & & Between rows & Within rows \\
\hline Horizon & $1(2.1 \times 2.1)$ & 2000 & HpLV & 52 & 5 & 7 \\
\hline Horizon & $1(2.1 \times 2.1)$ & 2000 & HрMV & 24 & 8 & 21 \\
\hline Horizon & $1(2.1 \times 2.1)$ & 2000 & AHLV & 30 & 2 & 0 \\
\hline Horizon & $2(4.3 \times 1.0)$ & 2000 & HpLV & 71 & 0 & 30 \\
\hline Horizon & $2(4.3 \times 1.0)$ & 2000 & HpMV & 29 & 0 & 70 \\
\hline Horizon & $2(4.3 \times 1.0)$ & 2000 & AHLV & 35 & 8 & 25 \\
\hline Nugget & WSU $(2.1 \times 2.1)$ & 1993 & HpLV & 27 & 2 & 6 \\
\hline Nugget & WSU $(2.1 \times 2.1)$ & 1993 & HpMV & 10 & 0 & 25 \\
\hline Nugget & WSU $(2.1 \times 2.1)$ & 1993 & AHLV & 23 & 7 & 9 \\
\hline Nugget & WSU $(2.1 \times 2.1)$ & 1994 & HpLV & 44 & 4 & 8 \\
\hline Nugget & WSU $(2.1 \times 2.1)$ & 1994 & HpMV & 15 & 2 & 25 \\
\hline Nugget & WSU $(2.1 \times 2.1)$ & 1994 & AHLV & 35 & 9 & 0 \\
\hline Nugget & WSU $(2.1 \times 2.1)$ & 1995 & HpLV & 74 & 0 & 25 \\
\hline Nugget & WSU $(2.1 \times 2.1)$ & 1995 & HpMV & 32 & 2 & 8 \\
\hline Nugget & WSU $(2.1 \times 2.1)$ & 1995 & AHLV & 57 & 4 & 0 \\
\hline
\end{tabular}

a Percentage of rows with significant $(P=0.05)$ nonrandom sequence of healthy and infected plants. A nonrandom sequence was concluded if the Zstatistic (observed number of runs with a nonrandom sequence +0.5 - expected number of runs with a nonrandom sequence)/standard deviation)/total number of rows (16).

b Spacing between plants $(\mathrm{m})$ (between rows $\times$ within rows).

c An equal representative sample of three randomly selected leaves from each plant was tested for each virus by double-antibody sandwich enzyme-linked immunosorbent assay (10). Total numbers of plants tested in Horizon gardens 1 and 2 were 444 and 476 , respectively. Total numbers of plants tested in the WSU Nugget garden were 519 in 1993 and 1994, and 515 in 1995.

Table 3. Radial correlation analyses of the spatial aggregation of plants infected with Hop latent virus (HpLV), Hop mosaic virus (HpMV), and American hop latent virus (AHLV) in hop gardens of the cultivars Horizon (2000) and Nugget (1993, 1994, and 1995) in Washington State

\begin{tabular}{|c|c|c|c|c|c|c|}
\hline \multirow[b]{2}{*}{ Cultivar } & \multirow{2}{*}{$\begin{array}{l}\text { Garden and spacing } \\
\text { between plants }^{\mathbf{b}}\end{array}$} & \multirow{2}{*}{$\begin{array}{c}\text { Year of } \\
\text { evaluation }\end{array}$} & \multirow[b]{2}{*}{ Virus } & \multirow[b]{2}{*}{ Radial correlation $^{c}$} & \multicolumn{2}{|c|}{$\begin{array}{l}\text { Probability of a random distribution } \\
\text { of infected plants }{ }^{a}\end{array}$} \\
\hline & & & & & Between rows & Within rows \\
\hline Horizon & $1(2.1 \times 2.1)$ & 2000 & HpLV & ns & 0.44 & 0.66 \\
\hline Horizon & $1(2.1 \times 2.1)$ & 2000 & HpMV & ns & 0.98 & $0.01 *$ \\
\hline Horizon & $1(2.1 \times 2.1)$ & 2000 & AHLV & ns & 0.93 & 0.56 \\
\hline Horizon & $2(4.3 \times 1.0)$ & 2000 & HpLV & ns & 0.88 & $4.18 \times 10^{-6 *}$ \\
\hline Horizon & $2(4.3 \times 1.0)$ & 2000 & HpMV & ns & 0.13 & $0.04 *$ \\
\hline Horizon & $2(4.3 \times 1.0)$ & 2000 & AHLV & $\mathrm{ns}$ & 0.15 & $7.43 \times 10^{-6 *}$ \\
\hline Nugget & WSU $(2.1 \times 2.1)$ & 1993 & HpLV & ns & 0.81 & 0.12 \\
\hline Nugget & WSU $(2.1 \times 2.1)$ & 1993 & HpMV & ns & 0.91 & 0.05 \\
\hline Nugget & WSU $(2.1 \times 2.1)$ & 1993 & AHLV & $r=5^{*}$ & $5.06 \times 10^{-3} *$ & $1.64 \times 10^{-6 *}$ \\
\hline Nugget & WSU $(2.1 \times 2.1)$ & 1994 & HpLV & ns & 0.38 & 0.47 \\
\hline Nugget & WSU $(2.1 \times 2.1)$ & 1994 & HpMV & ns & 0.26 & $1.23 \times 10^{-2} *$ \\
\hline Nugget & WSU $(2.1 \times 2.1)$ & 1994 & AHLV & ns & 0.35 & $1.78 \times 10^{-5 *}$ \\
\hline Nugget & WSU $(2.1 \times 2.1)$ & 1995 & HpLV & ns & 0.16 & $2.12 \times 10^{-3 *}$ \\
\hline Nugget & WSU $(2.1 \times 2.1)$ & 1995 & HpMV & ns & 0.22 & $8.02 \times 10^{-3 *}$ \\
\hline Nugget & WSU $(2.1 \times 2.1)$ & 1995 & AHLV & ns & 0.54 & $1.00 \times 10^{-2} *$ \\
\hline
\end{tabular}

a Probability of adjacent pairs of plants (healthy or infected) either within or between rows (13). Significance $(P<0.05)$ is denoted by an asterisk $(*)$.

${ }^{\mathrm{b}}$ Spacing between plants $(\mathrm{m})$ (between rows $\times$ within rows).

${ }^{\mathrm{c}}$ Radial correlation (13) was significant if there were more pairs of plants (healthy or infected) than expected in all directions. ns $=$ not significant at the $5 \%$ level. Significance $(P<0.05)$ is denoted by an asterisk $(*)$. 
years (Table 2). Significant radial correlation of plants infected with AHLV was detected in 1993 , but significant $(P<0.05)$ correlation was detected only within rows in 1994 and 1995 (Table 3).

\section{DISCUSSION}

All three carlaviruses (HpLV, HpMV, and AHLV) were detected in gardens of the hop cultivars Horizon and Nugget after relatively short cropping periods of up to 3 years after planting virus-free material. The presence and spread of these viruses was anticipated due to the presence of the aphid vector $P$. humuli (9). However, the incidence of HpMV was lower than HpLV in both cultivars at all sampling times. This indicates that a wider range of aphid species may be capable of transmitting HpLV, HpLV is more efficiently transmitted by $P$. humuli or by mechanical means, gardens were closer to sources of HpLV inoculum, or plants had a higher titer of HpLV that would, in turn, facilitate virus transmission. Similarly, the lower incidence of plants infected with HpMV may reflect that these cultivars were more resistant to infection by HpMV than HpLV, or transmission only by colonizing aphids such as $P$. humuli rather than by more transient aphid populations. However, HpMV has been shown to be transmitted by Macrosiphum euphorbiae $(1,22)$ and Myzus persicae (1), which do not colonize hops. Bock (8) suggested that the high population densities of $P$. humuli on hop indicate this aphid is the most economically important vector of HpMV. Similar rates of spread of HpLV have been recorded in the UK, where $P$. humuli is endemic $(3,4,5)$. However, the incidence of HpMV in the UK is also generally high in hop gardens. After planting virus-free hops in the UK, $50 \%$ of the plants were infected with HpMV within a year of planting (26). In a similar study, $42 \%$ of plants were infected with HpMV 1 year after planting, while 1 year later, $81 \%$ of plants were infected (4). The low levels of HpMV detected in the current study may also reflect differences in transmission efficiency among strains of HpMV in the United States and the UK, or differences in virus titer in infected plants. The rate of spread of the carlaviruses was much slower in studies conducted in Australia $(21,23)$ and New Zealand (14), where $P$. humuli does not occur. The difference in rate of spread of carlaviruses in regions where $P$. humuli is endemic compared with regions where this vector is absent also suggests this aphid species plays an important role in the transmission of these viruses. However, the role of variation in virus strains cannot be dismissed. Further work is required to determine the efficiency with which $P$. humuli (and other aphid species) transmit the three carlaviruses and whether aphid population levels on hop influence the rate of spread of the viruses.
The incidence of ilarviruses detected in both cultivars in this study was very low. Similar studies in the UK revealed that 4 years after planting virus-free material, $30 \%$ of plants of the cultivar Northern Brewer were infected with ilarviruses. Conversely, infection was not detected in the cultivar Wye Northdown until 4 years after planting (28). In 5- to 9-year-old New Zealand hop gardens of unknown original virus status, the incidence of ilarviruses ranged from 9\% in the cultivar Alpharoma to $16 \%$ in the cultivar Superalpha (14). In Australia, the rate of infection and spread of PNRSV and ApMV is highly variable. In the cultivar Pride of Ringwood, ilarviruses were not detected in several 19-yearold gardens. However, almost $100 \%$ of the plants of cultivar Victoria were infected 7 years after planting virus-free material (23). Additional work is needed to gain a better understanding of factors affecting transmission of ilarviruses in hop.

Spatial analyses of the distribution of HpLV- and AHLV-infected plants of the cultivar Horizon in gardens 1 and 2 suggested transmission was associated with contact of basal growth between plants within rows. In garden 1 , where there was little contact of basal growth between plants early in the season, the random distribution of plants infected with HpLV and AHLV suggested transmission primarily by alate aphid vectors. In garden 2, where contact of basal growth occurred within rows throughout the season, the pattern of plants infected with HpLV and AHLV was predominantly correlated within rows and too anisotropic for significant radial correlation to be detected. This suggests the movement of aphid vectors was preferentially between plants within rows, assisted by the formation of "green bridges" of basal growth, or mechanical transmission of the viruses through cultural operations. However, the viruses (and HpMV) were probably introduced into the gardens by alate aphid vectors. The spatial distribution of plants infected with HpMV was not influenced by planting pattern, and in both gardens the distribution of infected plants was correlated predominantly within rows. This suggests HpMV was more mechanically transmissible than HpLV and AHLV in the cultivar Horizon, and transmission within the garden may occur primarily as a result of cultivation activities.

Analyses of the spatial distribution of plants of the cultivar Nugget infected with HpLV revealed a random distribution in 1993 and 1994, but in 1995 infected plants were aggregated within rows in the direction of garden traffic. This suggested introduction of HpLV into the garden by alate aphid vectors from sources outside the garden, and spread of $\mathrm{HpLV}$ from those infected plants was predominantly within rows. This may reflect enhanced movement of apterous aphids in association with garden traffic, or direct mechanical trans- mission during cultural operations. The spatial pattern of plants infected with HpMV was similar to that observed in Horizon gardens with the same plant spacing and direction of garden traffic. The spatial pattern of plants infected with AHLV was correlated radially in 1993, but in 1994 and 1995 it was anisotropically aggregated in the direction of garden traffic. This suggests introduction of AHLV into the plot by alate aphid vectors (probably a colonizing aphid species such as $P$. humuli), while garden traffic was the primary factor causing transmission of AHLV in subsequent years. The extent and direction of basal growth has also been demonstrated to affect the spatial distribution of hop plants infected with HpLV and HpMV in Australian gardens (22). In that study, when contact of basal growth was restricted between plants in both directions by applications of desiccant herbicide, the distribution of HpLV- and HpMV-infected plants was random, suggesting exclusive transmission by alate aphids. Conversely, when basal growth contact was encouraged along rows through movement of garden traffic, the distribution of HpLV- and HpMV-infected plants was also autocorrelated within rows (22). There have been no reports of AHLV in Australia.

This study was the first quantitative assessment of the incidence and spatial distribution of virus-infected plants within gardens of the hop cultivars Horizon and Nugget in Washington State. Temporal changes in the incidence and spatial distribution of plants infected by HpLV, HpMV, and AHLV were also demonstrated on the cultivar Nugget. These studies may raise awareness of the potential impact of horticultural practices on infection of hop plantings by viruses. Further studies will concentrate on the relative efficiencies of a range of aphid species at transmitting the carlaviruses and the effects of factors such as virus titer on the acquisition efficiency of aphid vectors.

\section{ACKNOWLEDGMENTS}

We thank Tara Basgall for excellent technical assistance, Frank Ferrandino for his advice on radial correlation analysis, Frank Hay for constructive discussion, the hop growers who participated in this study for their cooperation, and the Washington Hop Commission and Australian Hop Marketers for their support of the project. This work was funded through the Australian Academy of Science's Scientific Visits to the USA for Young Australian Researchers program.

\section{LITERATURE CITED}

1. Adams, A. N., and Barbara, D. J. 1980. Host range, purification and some properties of hop mosaic virus. Ann. Appl. Biol. 96:201-208.

2. Adams, A. N., and Barbara, D. J. 1982. Host range, purification and some properties of two carlaviruses from hop (Humulus lupulus L.): Hop latent and American hop latent. Ann. Appl. Biol. 101:483-494.

3. Adams, A. N., Barbara, D. J., and Clark, M. F. 1982. The occurrence and some properties of three carlaviruses infecting hop plants (Humulus lupulus L.) in England. Acta Hortic. 
130:243-247.

4. Adams, A. N., Barbara, D. J., Clark, M. F., Flegg, C. L., and Thresh, J. M. 1977. Virus diseases of hop. Rep. E. Malling Res. Stn. 1976:147.

5. Adams, A. N., Barbara, D. J., Clark, M. F., Manwell, W. F., and Thresh, J. M. 1979. Virus diseases of hop. Rep. E. Malling Res. Stn. 1978:102-103.

6. Anonymous. 1980. Research results of the Bavarian Institute for Soil Culture and Plant Production, Division Hops. Bavarian Inst. Soil Cult. Plant Prod. and German Soc. Hop Res. Ann. Rep. for 1980.

7. Anonymous. 2000. Hop production in the Pacific Northwest states of the USA. Hop Growers of America. Published on-line.

8. Bock, K. R. 1967. Hop mosaic virus. Rep. E. Malling Res. Stn. 1966:163-165.

9. Campbell, C. A. M., and Cone, W. W. 1994. Influence of Predators on Population Development of Phorodon humuli (Homoptera: Aphididae) on Hops. Env. Entomol. 23:13911396.

10. Clark, M. F., and Adams, A. N. 1977. Characteristics of the microplate method of enzyme-linked immunosorbent assay for the detection of plant viruses. J. Gen. Virol. 34:475-483.

11. Eppler, A. 1994. Ecology of aphids on hops and its significance to spread of hop viruses. Z. Pflanzenkrankh. Pflanzenschutz 102:2-15.

12. Eppler, A., and Dahdahbiglou, R. 1991. Experiments on the non-vectorial transmission of PNRV in hops. Med. Fac. Landbouww. Rijksuniv. Gent. 56:577-587.
13. Ferrandino, F. J. 1998. Past nonrandomness and aggregation to spatial correlation: 2DCORR, a new approach for discrete data. Phytopathology 88:84-91.

14. Hay, F. S., Close, R. C., Fletcher, J. D., and Ashby, J. W. 1992. Incidence and spread of viruses in hop (Humulus lupulus L.) in New Zealand. N.Z. J. Crop Hortic. Sci. 20:319327.

15. Klein, R. E., and Husfloen, S. D. 1995. Incidence of five viruses in hop (Humulus lupulus L.) in the Pacific Northwest. Plant Dis. 79:425.

16. Madden, L. V., Louie, R., Abt, J. J., and Knoke, J. K. 1982. Evaluation of tests for randomness of infected plants. Phytopathology 72:195-198.

17. Maixner, M. 1993. Spatial pattern analysis for epidemiological studies on grapevine diseases. Proc. Meeting International Congr. Virus Dis. Grapevine, 11th.

18. Munro, D. 1987. Viruses infecting hop, $H u$ mulus lupulus, in Australia. Aust. J. Agric. Res. 38:83-90.

19. Paine, J. 1953. Insect vector studies with mosaic and other virus diseases of the hop. Rep. E. Malling Res. Stn. 1952:120-123.

20. Paine, J., and Legg, J. T. 1953. Transmission of hop mosaic by Phorodon humuli (Shranck). Nature 171:263-264.

21. Pethybridge, S. J. 2000. Epidemiology of viruses infecting hop (Humulus lupulus L.) in Australia. Ph.D. thesis. University of Tasmania, Australia.

22. Pethybridge, S. J., Wilson, C. R., Ferrandino, F. J., and Leggett, G. W. 2000. Spatial analy- ses of viral epidemics in Australian hop gardens: Implications for mechanisms of spread. Plant Dis. 84:513-515.

23. Pethybridge, S. J., Wilson, C. R., Sherriff, L. J., Leggett, G. W., and Munro, D. 2000. Viru incidence in Australian hop (Humulus lupulus L.) gardens and cultivar differences in susceptibility to infection. Aust. J. Agric. Res. 51:685-689.

24. Sokal, R. R., and Rohlf, F. J. 1981. Biometry, 2nd ed. W. H. Freeman \& Co., San Francisco.

25. Sutula, C. L., Gillett, J. M., Morrissey, S. M and Ramsdell, D. C. 1986. Interpreting ELISA data and establishing the positive-negative threshold. Plant Dis. 70:722-726.

26. Thresh, J. M., and Adams, A. N. 1983. Hop mosaic disease. Rep. E. Malling Res. Stn. 1982:173-175.

27. Thresh, J. M., Barbara, D. J., and Ormerod, P. J. 1988. The incidence and spread of prunus necrotic ringspot virus in English hop plantings. Pages 71-82 in: Proc. Int. Workshop Hop Virus Diseases, Giessen.

28. Thresh, J. M., and Ormerod, P. J. 1973. Virus diseases of hop - spread of prunus necrotic ringspot virus in hop. Rep. E. Malling Res Stn. 1972:163-164.

29. Von Weschmar, W. B., Brits, G., and Coleman, T. 1988. Viruses in hops and aspects of virus epidemiology and hop production in South Africa at $34^{\circ}$ southern latitude. Page 33-42 in: Proc. Int. Workshop of Hop Virus Diseases, Giessen.

30. Yu, J., and Liu, Y. 1987. The occurrence of three viruses in hop (Humulus lupulus L.) in China. Plant Pathol. 36:38-44. 